\title{
Foreign Land Acquisitions and institutional distance
}

\author{
Prof. Valentina Raimondi \\ Dept. Environmental Science and Policy, University of Milano \\ Via Celoria 2, 20133 Milan, Italy
}

Prof. Margherita Scoppola

Dept. Political Sciences, Communication and International Relations, University of Macerata, Via Don Minzoni 2, 62100 Macerata, Italy 


\begin{abstract}
This paper investigates whether and how the distance in the quality of institutions between the investing and target country affects the pattern of Foreign Land Acquisitions (FLA). We estimate a panel gravity-like equation to assess the impact of the institutional distance on the amount of land acquired and the number of contracts signed. Our results show that the institutional distance significantly affects both the number of contracts and the amount of land, but that the direction of these effects varies according to the geographical region and the relative strength of institutions in the target countries, with Africa following a pattern of its own.
\end{abstract}

Keywords: Foreign Land Acquisitions, gravity model, developing countries, institutions

\title{
1. INTRODUCTION
}

Media reports of the rapid growth in the number of foreign land acquisitions (hereinafter, FLA) in many developing countries have brought the phenomenon to the attention of the international community. Early estimates reported the acquisition of millions of hectares, in few years, by private firms, private equity or governments (e.g. Von Braun, Meinzen-Dick, 2009). The rise in commodity prices and the lack of attractive alternative investment opportunities following the 2008 financial crisis led to marked increases in the demand for agricultural land by foreign firms. Recent studies emphasize the distinguishing features of FLA: the emergence of South-South flows, with new investors from developing countries as well as the Gulf states; the rapid expansion of North-South FLA in new sectors (e.g., biofuels); the concentration of FLA in least developed countries; the direct involvement of governments in the deals, especially those of target countries (e.g. Von Braun, Meinzen-Dick, 2009; UNCTAD, 2009; Cotula et al, 2009; World Bank, 2011; Arezki et al, 2015; Anseeuw et al 2012).

Following this wave of acquisitions, the nature, drivers and implications of FLA have become one of the most hotly debated development issues (Schoneveld, 2014). On one hand, part of the media and NGOs refer to it as the new "land grab". Their major concerns are the lack of transparency regarding land allocations and the fact that FLA generally favors the expansion of large-scale-export oriented agricultural production. The 
fear is that they may displace local communities from the land, with potentially negative effects on the rural poor and the overall food security of the host economy. On the other hand, FLA are perceived as an opportunity to reverse the long-term trend of under-investment in agriculture in developing countries; if this is the case, a new wave of (foreign) investment in agriculture could help create the pre-conditions for sustained development (World Bank, 2011; FAO, 2013).

Nowadays it is widely held that not all FLA are "land grabs", yet not all FLA result in agricultural investments fostering growth and development in the developing countries (e.g. Cotula et al., 2009; Wolford et al., 2013). In fact, the implications of FLA largely depend upon the nature and the reasons for such investments. A number of factors are considered as particularly relevant, such as the actual investments made by foreign investors; employment creation and the development of infrastructure; whether FLAs involve negative environmental externalities and/or knowledge and technological spillovers; the nature of the acquired land (is it unused land or do foreign investors compete for land with the local population?); consultation with the local community (Cotula et al 2009; FAO, 2013; Messerli et al 2014; Kleemann, Thiele, 2015; Nolte, Voget-Kleschin, 2014).

The debate about the impacts of FLA is closely related to the debate about the likely drivers of FLA. A key issue is the role played by institutions. It is often argued that weak governance in general terms, and more specifically insecure land tenure, foster the most negative potential implications of FLA such as forced dispossessions, speculation, and lack of transparency. Based on these arguments, international organizations recommend a number of "good governance practices" (World Bank, 2011; FAO, 2013). ' On the other hand, the suspicion is that weak governance could itself be a major "locational" driver of large-scale acquisitions. Indeed, the weaker the governance - in particular a weak land tenure system, a weak legal environment, and a high level of corruption - the easier it is for the investor to acquire large-scale portions of land, with little effective opposition from local communities. This contrasts with the common assumption that countries with a higher quality of the institutions attract more foreign investment. Better institutions in target countries are expected to increase productivity, to reduce corruption and uncertainty and, by improving the investment climate, are expected to promote foreign direct investments (FDI). Empirical studies, by and large, confirm this positive impact for the economy as a whole and/or for manufacturing industries (e.g. Wei, 2000; Stein, 
Daude, 2001; Globerman, Shapiro 2002; Benassy-Quere et al, 2007). Nowadays, a considerable number of published case studies have significantly contributed to improving our knowledge of FLA in specific areas and industries (e.g. FAO, 2013). However, there have been few analyses of the phenomenon at the global and cross-country level. The few empirical studies estimating the impact of institutional variables on FLA have not found clear-cut evidence and the results are often not robust. Indeed, only a few papers found that poor land governance (Arezki et al, 2015) and corruption (Bujiko et al, 2016) in the host country negatively affect FLA, while the impact of several measures of institutional quality tends to have little influence in most studies.

This paper aims at contributing to this strand of the literature by providing further empirical evidence on the impact of the quality of institutions on FLA. We draw on existing literature and try to fill in some of the gaps on three issues in particular.

First, we investigate how the institutional "distance" between the target and the investor country affects FLA. Indeed, it is highly likely that the overall effects of institutional quality on FLA is country-pair specific. Previous literature on FDI found that, as multinational firms prefer a similar institutional environment, the greater the institutional distance, the lower the foreign investments (e.g. Bénassy-Quéré et al 2007; Aleksynska, Havrylchyk, 2013; Cezar, Escobar, 2015; Demir, Hu, 2016). Does institutional distance matter for FLA as well? This may well be relevant, as firms from South may have an "institutional" comparative advantage when investing in land in developing countries, with respect to firms from North. This may provide an additional perspective on the determinants of the growth of South-South FLA. Further, considering the institutional distance - instead of countries' institutional quality levels - may contribute to explain the lack of robust evidence about the impact of institutional quality on FLA. To the best of our knowledge, the role of the distance in institutional quality in influencing FLA has been not investigated to date.

Second, we investigate how a number of additional factors may partly explain the lack of clear-cut evidence on the impact of institutional quality on FLA. While many studies include, as dependent variable, a count variable, here we consider two different measures of FLA, the number of contracts and the amount of hectares acquired, in that they provide insights into two distinct effects on FLA. Indeed, while the number of 
contracts can be considered as a proxy for the number of firms involved in FLA, the amount of land proxies the size of the investments. The literature has shown that institutional distance reduces FDI through two distinct channels: by reducing the number of firms involved - the so-called extensive margin - and the size of investments - the intensive margin (Cezar, Escobar, 2015). We, therefore, check whether this also holds for FLA. Moreover, previous literature on FDI has shown that the pattern in Africa is different from the one observed in other regions (Asiedu, 2002 and 2006) and that the impact of institutional distance varies according to the features of the target country. Hence, we check whether the responsiveness of FLA to the quality of institutions in Africa and in countries with weak institutions differs from other regions.

Third, we address the issues of FLA data, concerning the quality and the time dimension. Indeed, one important barrier to research in this field is the lack of official cross-country data. As a consequence, studies have based their analyses on information collected by the media or from other unofficial sources and their conclusions are often challenged because of the poor quality of the data on which they are based. "We use the most widely used database, the Land Matrix, which includes data from various unofficial sources. First, for each acquisition, we checked the source and the data and, secondly, we ranked the various types of sources in terms of quality. The robustness of our results to the use of different data sources is checked. In addition, we work with a panel dataset to take into account the time dimension of the data. ${ }^{\text {iii }}$ Previous studies - with the only exception of Bujko et al (2016) - do not consider the time dimension, but use Land Matrix data in a cross-section framework.

We use an unbalanced panel of bilateral land acquisitions data including 66 investor countries, 70 target countries and 16 years; following the literature analysing the determinants of FDI, we estimate a panel gravity-like equation using the Poisson Pseudo-Maximum-Likelihood estimator (hereinafter, PPML) proposed by Santos Silva and Tenreyro (2006). The gravity equation is the most widely used empirical specification for both FDI and trade, as it has been shown to explain both quite well. While theoretical foundations for trade gravity equations are well established, the theoretical literature justifying the use of gravity equations to estimate FDI is more recent. We base our empirical specification on Bergstrand and Egger (2010, 2013a and 2013b) and Kleinert and Toubal (2010) who provide a rationale for estimating timevarying gravity equations of FDI. 
Our results suggest that, by and large, the greater the gap in governance and democracy, the lower the amount of FLA; this negative relation between institutional distance and FLA is in line with the findings of the literature on FDI. Results also confirm our hypothesis that investments in Africa follow a different pattern, in that the distance in governance favours large-scale investments. By using two measures of FLA as dependent variables we disentangle the effects of institutional distance on the number of firms (the extensive margin) and on the size of investments and show that, in a number of countries, the greater the gap in governance, the lower the amount of contracts, but the higher the hectares of acquired land. Finally, the potentially low quality of some of the data sources does not undermine the main messages coming from our estimations; indeed, results are quite stable when controlling for the reliability of the data source used.

The paper is organised as follows. The next section provides the background on the expected determinants of FLA and, more specifically, about the likely impacts of institutional quality. Section 3 illustrates our empirical strategy and the econometric issues. The fourth section illustrates the data used for the dependent and the explanatory variables. Section 5 illustrates and discusses the results of our estimations, while the final section offers concluding remarks.

\section{THE DETERMINANTS OF FOREIGN LAND ACQUISITIONS: BACKGROUND}

There is a substantial lack of theoretical work on the determinants of FLA. In general terms, it is reasonable to consider FLA as a particular type of FDI. In many African countries foreign firms agree on long-term land leases (usually one century) with the local government (Cotula, 2011). This happens frequently in the exploitation of natural resources and, because of the long-term duration of the lease and the frequent commitment of foreign firms to make investments, this type of arrangement is considered equivalent to FDI (Venables, Ruta, 2012). In Latin American or Asian countries, where land is mainly owned and managed by the private sector, FLA more frequently implies the full transfer of ownership to a foreign firm. Both longterm leases and land ownership transfers qualify for FDI. The literature has shown that investing firms are often involved in down-stream industries (international traders of agricultural products or processing firms in food and energy industries) and they vertically integrate upwards in order to access agricultural raw materials 
(UCTAD, 2009; Cotula et al 2009; World Bank, 2011). A large part of FLA can thus be considered as oneway vertical FDI.

The literature on FDI has extensively analyzed their economic determinants. Modern general equilibrium models, such as the knowledge-capital model (Markusen, 2002; Markusen, Maskus, 2002), simultaneously explain both horizontal and vertical FDI. According to the knowledge-capital model, horizontal FDI is likely to prevail if countries are similar in size and in relative endowments, and trade costs are high, while vertical FDI is more likely to occur when countries differ in factor endowments. Of particular interest for this paper are the contributions by Bergstrand and Egger (2007, 2010, 2013a and 2013b); they extend the knowledgecapital model to three factors and three countries and propose a theoretical rationale for estimating the determinants of horizontal and vertical FDI by means of a gravity equation. In their model differences in countries' endowment drive the location of the different stages of production. The greater the differences in factor endowment, the higher vertical FDI appears to be. The empirical specification of the gravity equation developed by Bergstrand and Egger (2013a and 2013b) is drawn from their general equilibrium model.

In our empirical exercise, we build on this theoretically founded specification of the gravity equation for FDI, while taking into consideration the key factors driving the location of FDI in the exploitation of natural resources, i.e. the difference in endowments of natural resources (Venables, Ruta, 2012). In the specific context of FLA, the most obvious source of comparative advantage is the relative endowment of land and water (Arezki et al 2015; Lay, Nolte, 2014). FLA mostly source from countries where land and water are scarce and are located in countries rich in land and water.

Our main interest is the role of institutional variables as determinants of the FLA. A number of studies on FDI has shown that good institutions in the destination country and low corruption, by and large, positively affect FDI (e.g. Wei, 2000; Stein, Daude, 2001; Globerman, Shapiro, 2002). These results confirm the common assumption - based on the growth and financial literature - that better institutions, by increasing productivity, improving the investment climate, reducing corruption and uncertainty in target countries, tend to have a positive effect on FDI. Other studies have distinguished the impact of democracy from the impact of good governance: the former, by increasing the "voice" of the weakest part of the population (e.g. unskilled workers or rural poor) is likely be negatively correlated with FDI; more pluralism may increase the 
bargaining power of workers and rural poor and this, by reducing the market power of multinational firms, may discourage investment. Conversely, good governance is generally associated with more FDI (Li and Resnick, 2003; Berden et al, 2014). Asiedu and Lien (2011) have investigated the role of the political regime and found that FDI are fostered by autocracy, especially in countries where natural resources (minerals and oil) are dominant exports. One reason is that natural resources - and more specifically FLA - are largely controlled by governments of host countries. Close ties with host governments are crucial for foreign investors and this is easier under autocracy.

As for FLA, it has often been argued that, unlike general FDI, poor governance in the destination countries fosters FLA. The argument is that the weaker the governance (in particular, a weak land tenure system, a weak legal environment, and a high level of corruption), the easier it becomes for the investor to acquire large-scale portions of land. Institutional variables have been included as determinants of FLA, but the results are controversial. Arezki et al (2015) found that general institutional variables do not affect FLA, while the quality of land governance in the host countries negatively influences acquisitions. In the paper by Lay and Nolte (2014) the impact of institutions is generally not significant, although their results are not robust to the different specifications and estimators used. Bujko et al (2016) find that a low level of corruption, regulatory quality and rule of law all negatively influence FLA, but once again the results are not always robust to different specifications and estimators.

More recent evidence has shown that FDI is also negatively affected by the institutional "distance", measured as the absolute difference of institutional quality between the origin and the destination countries (e.g. Bénassy-Quéré et al 2007; Aleksynska, Havrylchyk, 2013; Cezar, Escobar, 2015; Demir, Hu, 2016). The literature has also shown that this impact differs depending on the country of origin of the investing firm and the destination country (developed versus developing countries). Indeed, this negative effect has been found to be lower for South-South FDI (Demir, Hu, 2016), for inward - with respect to outward - FDI in OECD countries (Cezar, Escobar, 2015), and for those developing countries endowed with large reserves of natural resources (Aleksynska, Havrylchyk, 2013).

The basic idea behind the inclusion of institutional distance among the FDI determinants is that firms from countries with weak institutions are likely to face lower costs - when investing in countries with weak 
institutions - than investors from countries with strong institutions (Bénassy-Quéré et al., 2007; Aizenman, Spiegel, 2006). Recently Cezar and Escobar (2015) have more formally analysed the impact of institutional distance on FDI within a Melitz-type heterogeneous firms framework (Melitz, 2003). Institutional distance influences the adaptation (fixed) cost for foreign firms: the more similar the institutional environment, the lower the adaptation cost. This implies that an increase in the institutional distance, by increasing the fixed costs of investing abroad, raises the productivity threshold above which FDI is profitable and, hence, reduces the number of firms engaged in FDI (the so-called FDI extensive margin). At the same time, an increase in institutional distance also reduces the amount of FDI for already established multinational firms (the FDI intensive margin).

Drawing on this literature, we shall explore how the country-pair distance in the degree of democracy and governance may affect the pattern of FLA.

\section{EMPIRICAL STRATEGY}

As in previous empirical studies estimating the determinants of FLA (e.g. Arezki et al 2015; Lay, Nolte, 2014; De Maria, 2015), we use a gravity-like equation, albeit in a panel data framework. The main reason is that, as shown in the next section, the data cover rather a long period and time-varying factors are likely to significantly influence the pattern of FLA. Moreover, as highlighted by Daude and Stein (2007) and Bénassy-Quéré et al. (2007) for the FDI stock, we cannot exclude a priori the possibility that institutions are endogenous to FDI, as foreign investors, becoming a constituency that might demand better institutions, might generate a positive feedback on the quality of institutions in the host country. Thus, because FLA is a peculiar type of FDI, we cannot rule out this possible endogeneity. The gravity literature has shown that a panel approach is more appropriate when adjusting for endogeneity than instrumental-variable and controlfunction approaches (Baier, Bergstrand 2007).

The empirical specification of the gravity equation developed by Bergstrand and Egger (2010; 2013a and 2013b) considers three groups of explanatory variables. The first group includes bilateral economic size and economic similarity. They are both expected to positively affect FDI. The second group consists of the usual gravity covariates (distance, contiguity and language). While distance is expected to negatively affect 
vertical FDI, language and contiguity are expected to exert a positive effect. The third group includes variables measuring relative factor endowments. In this specific context, we consider countries' relative endowment in natural resources and, in particular, in land endowment. Our expectation is that the FLA will be higher, the more the investor (target) country is relatively scarce (abundant) in land.

It is worth mentioning that our dependent variable is somewhat different from the usual measures of FDI (stocks, flows or total sales of the subsidiaries). As detailed in section 4, data on FLA provide the number of contracts and the amount of land acquired. We use both measures of FLA as dependent variables, in order to distinguish the impact on the number of contracts (which proxies the number of firms) from the impact on the amount of land (which proxies the size of investments).

Our basic estimated equation is:

$\ln f l a_{i j, t}=\beta_{0}+\beta_{1} X_{i j, t}+\beta_{2} Z_{i j}+\beta_{3} I_{i j t}+\alpha_{i t}+\alpha_{j t}+\alpha_{t}+\varepsilon_{i j, t}$

Where $f l a_{i j t}$ is the stock of hectares (or of contracts) acquired by country $i$, in country $j$ at time $t, X_{i j, t}$ denotes a vector of control variables (i.e. relative factor endowment, economic size ${ }^{\mathrm{iv}}$ ), $Z_{i j}$ is a vector of gravity covariates including the geographical distance between countries, and two dummies equal to one if countries share a common language, or have previous colonial relationships, and zero otherwise; $I_{i j t}$ is a measure of institutional distance between the two countries.

A key issue of gravity specifications is how to control for multilateral price terms and the possible endogeneity of explanatory variables, as is the case here, of the institutional variables (see Anderson and van Wincoop 2003; Baier and Bergstrand 2007). In a panel data setting, the multilateral price terms tend to be time-variant, and so, the gravity equation should include time-varying country dummies to account for timevarying multilateral-resistance terms as well as to eliminate the bias from the gold-medal error identified by Baldwin and Taglioni (2006). In this way, variables that are difficult to measure, such as "infrastructure, factor endowments, multilateral trade liberalization, and unobserved time-specific shocks, will be captured by the importer-year and exporter-year fixed effects" (Magee 2008, p. 353). Thus, in our specification, we 
include investor country-year $\left(\alpha_{i t}\right)$ and target country-year $\left(\alpha_{j t}\right)$ fixed effects. Finally, the time dummy $\alpha_{t}$ captures the impact of time-varying factors on FLA, e.g. the shocks in international agricultural markets.

From an econometric point of view, the main issue in estimating the gravity equations above is related to the choice of the best estimator to identify the effect of institutional distance on FLA. The first issue to take into account is selection bias, as defined by Heckman (1979), arising from the high number of zeros in our dataset, as reported in the following data section. ${ }^{\vee}$ The second issue concerns heteroscedasticity, which leads to biased estimates when the gravity equation is log-linearized, rather than estimated in levels (SantosSilva and Tenreyro, 2006). The literature tackles these problems by applying either the Heckman selection correction (Helpman et al. 2008) or the PPML estimator proposed by Santos Silva and Tenreyro (2006). Due to the panel structure of our dataset, we prefer to use the latter estimator to avoid the incidental parameter problem of the first stage (probit) Heckman model. Moreover, Santos Silva and Tenreyro $(2006,2011)$ have shown that this estimator, robust to different patterns of heteroscedasticity and measurement error, is particularly suitable in the presence of many zeros.

\section{THE DATA}

\subsection{Foreign land acquisitions}

The most widely used data on FLA are those collected and classified by the Land Matrix. ${ }^{\text {vi }}$ This database contains domestic and transnational land acquisitions and reports, for each recorded deal, target country, location, investor name and country of origin, the "intention" of the deal (e.g. agriculture, energy, forestry, and so on), negotiation and implementation status (intended, concluded, failed), the size of the area, the nature of the deal (sale, lease or concession), the type of agreement (oral or written), the crops, and the data source type $^{\text {vii. }}$. Because our focus is on acquisition by foreign firms, we have considered only deals where at least one foreign firm is involved; further, we have limited our analysis to concluded deals (both oral and written). Overall, our database covers 1,050 deals. ${ }^{\text {viii }}$

The quality of the Land Matrix data is a major issue for empirical analyses. Land deals are notoriously opaque and often negotiated in secret. The release and transparency of information regarding such data vary 
widely across target countries. In a limited number of countries data on FLA are relatively easy to access. ${ }^{\mathrm{ix}}$ In other countries, for instance Sudan and Colombia, governments and firms do not release any information, so NGOs or the media are the main source. These have been criticised, not only because of the obvious disadvantages of unverified data, but also because of a tendency to overestimate the phenomenon (Oja, 2013; Schoneveld, 2014). Collection methodology and definitions may vary from country to country and errors often occur in recording the data. Since 2013, however, the Land Matrix has been considerably improved and the issue of data reliability addressed by including in the database the source, so that researchers can make their own judgement about data quality (Anseeuw et al, 2013). We have used this information to address the issue of data quality by following a two-step procedure.

In the first place, we have checked if the source and the data reported in the Land Matrix are still verifiable. We verified - for each of the 1,050 deals here considered - the availability of the source (research papers, institutional and companies websites, media reports) reported in the Land Matrix and the corresponding "size of the contract". When the sources reported in the Land Matrix were no longer available, alternative sources on the web have been considered, for each contract; firstly by looking for "official" data released by governments, then, in the absence of the latter, by analysing the investing firm's profile, including all companies controlled by the investor.

Secondly, we have classified all observations according to their main (verified) source of information. In the context of FLA, official data released by governments are, by and large, reliable. Less straightforward is how to consider other sources in terms of reliability. Following Schoneveld (2014), our hypothesis is that information released by firms is usually likely to be more reliable than information provided by other sources. The reason is that this information is generally verified by government agencies, for example for taxes purposes; in addition, in public companies also shareholders have an interest in checking the accuracy of the information released by firms. In our analysis two possible sources of data are thus considered: on the one hand, governments and firms, and, on the other, all other sources. In the econometric analysis, we then check the robustness of the results through the use of a different subsample of sources which corresponds to a better level of data quality. 
Finally, by using the investor-country origin and the target-country destination information reported by the Land Matrix dataset, the number of hectares acquired and the number of contracts have been aggregated at the country level and cumulated over the analysed period. Our final (bilateral) country level dataset includes the stock of FLA, from one investor country to a target country during the period 2000-2015, and considers 109 different countries: 43 are target countries only, 39 are only investing countries and 27 are both target and investor-countries (more details are in Table A1 in the appendix).

Accordingly, squaring the dataset, our unbalanced panel of bilateral data includes 66 investor countries, 70 target countries and 16 years. The idea behind the selection of countries included in the sample is that all 66 countries reporting at least one contract with one of the 70 target countries are considered as potential investors over the analysed period. This implies a considerable number of zeros, mainly concentrated in the years 2000-2006, as the largest part of contracts were made after the 2007 crisis (see Figure 1). This high percentage of zeros is an important issue that needs to be properly addressed, as explained in the econometric section.

Overall, data from reliable sources, i.e. those from governments and firms, account for about two thirds of the total hectares reported by the Land Matrix (see Table A2 in Appendix). Government data are much more frequent when acquisitions occur in East Asia (almost two thirds of total hectares). East and Southern Africa is the more problematic region in terms of data reliability; indeed, almost half of the data comes from sources other than firms and governments. Thus, if we used only the data sourced from governments and firms, almost $80 \%$ of the excluded hectares would be in Africa.

Our dataset confirms that Africa, and especially West Africa, hosts the largest part of FLA, accounting for about $54 \%$ of total land. ${ }^{x}$ East Asia accounts for about one quarter of total land, while the Americas only for $10 \%$. It is worth noting that all target countries are from South.

On the investor side, the main regions involved are the Americas, Western Europe ${ }^{\mathrm{xi}}$ and East Asia and the Pacific, which jointly make up $80 \%$ of total land acquired (Table 1), with the United States, United Kingdom, and Malaysia as main investors (38\%). North America and Western Europe account for half of the 
hectares acquired, while the other half is from South firms, mostly from East Asia. Thus, South-South FLA account for half of the hectares acquired.

Table 1 reports also the number of contracts by geographical region and shows a slightly different pattern. ${ }^{\text {xi }}$ Indeed, the share of some regions as investor or target region is different when measured in terms of hectares as opposed to contracts. The reason is that the average size of the acquisitions is an important country-pair characteristic. In general terms, the average size of the acquisitions is higher in African countries and lower in Latin American and Asian countries; further, the size of FLA by North American firms is, on average, higher than those by European and Asian firms.

\subsection{Gravity and control variables}

Data on country distance, and the other gravity variables used in similar exercises such as dummies for common language and colonial relationship, come from CEPII (Centre d'Etude Prospectives et d'Informations Internationales). Dummies are equal to 1 if two countries speak a common language or if countries were once in a colonial relationship, and zero otherwise.

Following Bergstrand and Egger (2010; 2013a and 2013b) bilateral economic size is measured by the log of the sum of the countries' GDP. GDP data come from the World Development Indicators of The World Bank (WDI). ${ }^{\text {xiii }}$

As for the relative factor endowment ratio $(R F E)$, here we consider countries' relative endowment in agricultural land as a key factor driving the location of FLA. Following Kleinert and Toubal, (2010), who considered the relative endowment of countries in terms of skilled and unskilled labor, we compute $R F E$ as the difference between the share of the investor's agricultural land, in logarithm, and the share of the investor's non-agricultural land, in logarithm:

$R F E=\ln \left[A l_{i} /\left(A l_{i}+A l_{j}\right)\right]-\ln \left[N A l_{i} /\left(N A l_{i}+N A l_{j}\right)\right]$

with $A l$ being agricultural land and $N A l$ being non-agricultural land. ${ }^{\text {xiv }}$ Data on agricultural land are from WDI and include arable, under permanent crops and permanent pastures areas. It is worth mentioning that there is considerable disagreement about the "type" of land which mostly attracts FLA. On one hand, some studies conclude that FLA is mostly attracted by (target) countries relatively rich in uncultivated land or in 
forests (Arezki et al 2014); on the other hand, other studies highlight a more differentiated geographical pattern, and reveal that a considerable share of FLA is concentrated in highly populated and already cultivated areas (Messerli et al, 2014; Schoneveld, 2014). Our approach differs slightly from these studies, in that we consider the differences in land endowment between the investor and the target country. A high (low) RFE implies that the investor (target) country is relatively abundant in agricultural land. Hence, a negative impact of this variable on FLA means that the larger the RFE (i.e. the investor country is relatively abundant in agricultural land) and the lower is the amount of FLA. ${ }^{\mathrm{xv}}$

\subsection{Institutional and political variables}

There are many sources that provide ratings of the level of democratization, corruption, and governance. Because each measure and source has certain drawbacks, our choice is to include different variables from a variety of sources. ${ }^{x v i}$

For the level of democratization we use two measures; the first is a measure of political rights from the Freedom House (PolRights). It ranges between 1 and 7: a rating of 1 implies the presence of competitive parties and of an opposition that plays an important role. When the rating is 7 , political rights are absent. The second measure of democratization comes from the democracy index published in Polity IV (Polity). ${ }^{\text {xii }}$ It provides a single regime score that ranges from +10 (full democracy) to -10 (full autocracy) and reflects the openness and the competitiveness of the political process.

For the measurement of corruption we use two indexes: the Corruption Perception Index $(C P I)$ and the Control of corruption (Corr). The first, CPI, is provided by Transparency International. ${ }^{\text {xiii }}$ This is a composite index, a combination of surveys and assessments of corruption collected by a variety of reputable institutions, that measures, on a scale of ten, the level of perceived corruption of a given country's public sector. CPI ranges from 0 to 10 , with 0 corresponding to the highest level of corruption. The second index of corruption is the Control of Corruption taken from the World Governance Indicator (WGI) database compiled by World Bank. Control of corruption (Corr) captures perceptions of the extent to which public power is exercised for private gain, including both minor and major forms of corruption. It ranges from 0 to 100, with 100 being the lowest level of corruption. Although it might seem redundant to include two 
different indicators of the same issue, it should be acknowledged that these data do not measure corruption per se, but only opinions as to its prevalence, and measuring corruption remains a highly subjective task (Treisman, 2007).

In addition to the index of corruption, we use the other five institutional variables developed by Kaufmann et al (1999) and included in the WGI database. The first two concern the process by which governments are selected (and partially overlap with the aforementioned democracy indexes). Voice and Accountability (Acc) focuses on different indicators related to the political process, civil rights, and institutions that facilitate public participation in selecting the government, and freedom of expression and association, and free media. Political Stability and Absence of Violence/Terrorism (Stability) measures perceptions of the likelihood of political instability and/or politically-motivated violence, including terrorism. Two indexes concern the capacity of the government to effectively formulate and implement sound policies. Regulatory Quality (RegQuality) captures perceptions of the ability of government to formulate and implement sound policies and regulations that permit and promote private sector development. Government Effectiveness (Effectiveness) captures perceptions of the quality of bureaucracy, the competence of civil servants, the quality of public service provision, and the credibility of the government's commitment to its policies. Finally, two indexes measure the respect of citizens and the state for institutions. One is Control of corruption - above mentioned- and the second is Rule of Law $(R o L)$ which captures perceptions of the extent to which agents have confidence in and comply with the rules of society and, in particular, the quality of contract enforcement, property rights, the police, and the courts. All these variables range between 0 and 100, with the highest values corresponding to better institutions.

Finally, following Aleksynska and Havrylchyk (2013), we construct a simple average of these indicators (Inst.Quality) by using the six measures of institutional quality developed by Kaufmann et al (1999) from the WGI database.

To facilitate the comparison of the different measures, we follow Asiedu and Lien (2011) and uniform and normalize all institutional variables between zero and one, so that the highest value, 1 , always implies better governance, higher level of democratization and lower level of corruption. Finally, following Bénassy-Quéré 
et al. (2007) and Aleksynska and Havrylchyk (2013), we construct our measure of institutional "distance" as the absolute difference between the origin and the destination country.

Most of the institutional variables show a remarkably significant correlation; from an econometric point of view, this can induce serious problems of multicollinearity (Daude and Stein, 2007). Consequently, in our estimations we include one variable at a time.

A preliminary glance at the data shows that, by using the average Inst.Quality, most of FLA take place from countries with 'strong' institutions countries to those with 'weak' institutions. ${ }^{\text {xix }}$ In 2015 these acquisitions represent the $73 \%$ of hectares, but were more than $90 \%$ in 2000 . Indeed, the share of "weak-weak" FLA has increased from $3 \%$ to $17 \%$ of the total land acquired during the analysed period, and they account for even a higher share in terms of number of contracts (more than $25 \%$ ) (see Figure A1, in the appendix). Furthermore, data suggest that the relationship between the institutional distance and FLA may vary according to the characteristics of the target country, as the empirical literature has found for FDI in general (e.g., Demir, Hu, 2016; Cezar, Escobar, 2015; Aleksynska, Havrylchyk, 2013). More specifically, two characteristics of the target country seem to affect this relationship: the level of institutional quality and geographical location. Figure 2 plots, for African and non-African target countries, the total amount of hectares acquired (or the number of contracts), with respect to the institutional quality (Inst.Quality) of the target country, and to the distance between the investor and the target country as regards institutional quality. The size of the "circle" measures the stock of FLA for each country-pair, at the end of the analysed period (2015). When using hectares as a proxy for FLA, the pattern of African countries appears to be quite different from that of other target countries. In fact, for the former the larger the institutional distance and the higher the amount of land acquired, and this is especially true for target countries with very weak institutions. Conversely, for non-African countries institutional distance seems to be associated with less land acquisition. When using the number of contracts, we find much less difference between African and nonAfrican countries and higher institutional distance seems to be associated with a lower number of contracts for all target countries. Further, we note that the relationship between the number of hectares and institutional distance seems to be affected by the level of institutional quality in the target country. Indeed, when the latter is very low, greater distances are associated with larger FLA, while this is not the case for 
target countries with strong institutions. Figure 2 overall suggests that, as observed for FDI, the impact of institutional distance on FLA may depend on the nature of the destination countries, thus supporting the idea that Africa and countries with very weak institutions may follow a specific pattern. These hypotheses are explored in more detail in our econometric analysis.

\section{RESULTS}

Table 2 and Table 3 report the results obtained by using equation (1), when the dependent variable is the amount of the acquired land and the number of contracts, respectively. Starting with the traditional gravity variables, we observe that for, both FLA measures, geographical distance exerts a negative impact, as expected for vertical FDI, while common language has a positive impact. In particular, our findings show that country-pairs sharing a common language tend to invest $80 \%$ more in each other, than otherwise. ${ }^{x x}$ Conversely, the coefficients of "colonial relation" positively affect the number of contracts only; hence, historical colonial relationships increase the number of contracts, but not the number of hectares acquired.

Control variables are, by and large, significant across all estimations and with the expected sign: the sum of countries' GDP positively affects foreign investment in land, in line with the empirical literature on FDI and gravity. As for relative factor endowment, our findings confirm that this is a major driver of land acquisition. However, this is not the case when we use the number of contracts as dependent variable. Indeed, in this case the coefficient of RFE, albeit negative, is not significant (Table 3).

The impact of institutional distances is generally negative and significant, and this is so for both our dependent variables. ${ }^{x \times i}$ This result confirms expectations and the findings obtained by previous literature regarding total FDI (Bénassy-Quéré et al 2007; Demir, Hu, 2016; Cezar, Escobar, 2015; Aleksynska, Havrylchyk, 2013), suggesting that, all else being equal, the greater the gap in governance and democracy, the lower the amount of land acquired and the number of contracts.

In particular, considering the hectares acquired reported in table 2, a strong impact can be observed for four indexes. The most significant is that for CPI, i.e., the level of perceived corruption in a given country ; the size of coefficients suggests that, where there is no gap between the investor and target countries, the hectares acquired would be $50 \%$ higher, on average $\left[\delta F L A / \delta C P I=(1.7372 *(0.29-0) \approx 0.50] .{ }^{x \times i}\right.$ The second 
index captures compliance with the rule of law $(R o L)$, such as property rights: where the rule of law is the same, the hectares acquired would increase by $41 \%$, on average $[\delta F L A / \delta R o L=(1.017 *(0.40-0) \approx 0.41]$. The third index impacting on FLA is "Voice and accountability"; this estimated coefficient shows that a similar level, between investor and target country, of freedom of expression and participation in selecting a government would increase the FLA hectares by $29 \%[\delta F L A / \delta A c c=(0.7819 *(0.37-0) \approx 0.29]$. The fourth reflects the openness of the political process (Polity); it shows that a zero gap in democracy would increase the acquired hectares, on average, by $41 \%[\delta F L A / \delta P o l i t y=(1.2479 *(0.33-0) \approx 0.41]$. An example may help to better illustrate the negative effect of distance on FLA. Consider two target countries with very different levels of democratization: Laos, one of the least democratic countries (polity=0.15), and Uruguay, a country with a high democracy score (polity=1). Regression results of Table 2, Column (2), show that, ceteris paribus, an increase in democracy from the level of Laos to the level of Uruguay, by narrowing the gap with investor countries, would increase bilateral FLA by about $106 \%(=1.2479 \times(1-0.15))$ in terms of hectares acquired.

Finally, the effect of the institutional quality average index combines the impacts of each single component (column 5 to 10) and is negative but not significant (see column 11).

Results of estimations using the number of contracts as a dependent variable are reported in Table 3. Here, the impact of institutional distance is always negative and significant. The size of coefficients is rather high, highlighting the negative effect that the difference in institutions exerts on the number of contracts. An identical institutional quality index of two countries would increase the number of FLA contracts by 1.43 percentage points $[\delta F L A / \delta$ Inst. Quality $=(3.968 *(0.36-0) \approx 1.43]$.

Overall, the findings obtained from the estimations using the whole sample offer a number of interesting insights. For indexes measuring the level of democracy (Polity; PolRights and Voice and Accountability) and corruption (CPI; Corr) the impact on FLA - both measured as the number of hectares or the number of contracts - is always negative. Hence, target countries with a level of democratization or corruption similar to the one of investor countries attract more firms, and greater investment in land. In line with previous findings for general FDI (Cezar, Escobar, 2015), we find that, as regards foreign investments in land, political and (all except one) governance distances impact negatively both on the number of firms (in our context proxied by 
the number of contracts) and on the level of investment (in our case proxied by the number of hectares acquired).

\subsection{Is Africa different?}

As aforementioned, the literature has shown that FDI in African countries follows a different pattern from other regions (Asiedu, 2002, 2006). Hence, our hypothesis, also based on our descriptive analysis (see section 4, Figure 2), is that the findings obtained for all countries could be the result of different and contrasting patterns. For further insight, we estimate the same specifications of Tables 2 and 3 by splitting our dataset into two groups according to the target country, i.e., African and non-African countries. ${ }^{\text {xiii }}$ Figure 3 summarizes the impact of institutional gaps on FLA for the two groups of target countries.

The results for African countries show that, when using, as dependent variable, the stock of hectares of land acquired, the coefficients of a number of institutional distances - Corruption, Regulatory quality, Government Effectiveness, Political Stability, and the average institutional quality index (Inst.Quality) become positive and significant; ${ }^{x x i v}$ only the coefficients of variables measuring different levels of democratization (Polity, Political Rights and Voice and Accountability) maintain a negative and significant effect on FLA. In particular, for African countries, the distance in RegQuality, that is a government's ability to implement policies that permit and promote private sector development, turns out to be the most relevant. By removing this distance, e.g. by increasing "government ability" in African countries, the hectares acquired in the region would decrease by more than $103 \%$, on average.

When the dependent variable is the number of contracts, both democratic and governance distances always exert a negative effect. The most marked (negative) impact on the number of contracts is exerted by the distance in corruption $(C P I)$ and property rights $(R o L)$ : a gap equal to zero would increase the number of contracts, on average, by $37 \%$ and $44 \%$, respectively.

Thus, when FLA involves African countries, the greater the difference between investor and target countries in terms of governance, the greater the amount of land acquired, but not the number of contracts. Thus, the wider the gap in governance, the more likely is the prevalence of few large scale projects, instead of many 
small ones. This result confirms observations in our preliminary data analysis (see Figure 2). Conversely, the gap in democracy negatively affects both dependent variables.

Figure 3 reports results also for non-African countries and shows that - with the exception of Stability, Regulatory quality, and Government Effectiveness, whose coefficients are not significant in explaining the number of hectares acquired - governance and political distances exert a significant negative impact on both measures of FLA: the number of contracts and the hectares of land acquired. In particular, corruption (CPI) exerts a strong impact on FLA: with a zero gap in the level of corruption, hectares would increase by more than $90 \%$ and the number of contracts up to 1.7 times, on average. Hence, for non African countries, our findings are in line with those for general FDI: institutional distance negatively affects the number of firms and the size of the investment. While for FLA in Africa the gap in the ability of governments to effectively formulate and implement "sound" policies positively affects the level of investment, they do not affect the size of investments in non African countries. Finally, it is worth noting that the distance in corruption increases (reduces) the size of investment in African (non-African) countries.

The surprising results observed for the size of the investments in Africa are probably related to the different way in which land acquisitions are carried out compared with other regions. Indeed, in Africa host governments and local public administrations allocate most of the land, whereas in other continents land is mainly acquired through contracts with local private firms. Once contact with governments and local administrators in the target country has been made and contracts signed, firms from stronger governance countries find it convenient to increase their investments, probably to exploit economies of scale.

\subsection{Does the quality of institutions in the target countries matter?}

More than $65 \%$ of the hectares acquired - corresponding to less than half of the number of contracts (47\%) -

are located in countries where our institutional quality measure is below the median value. ${ }^{\mathrm{x} v}$ Preliminary analysis of the data suggests that the relationship between FLA and institutional distance varies according to the level of institutional quality in the target country (see Figure 2). Thus, to investigate this issue, we built a dummy equal to one when the average institutional quality index of target country falls below the median value (zero otherwise) and interact this dummy with the institutional quality distance between the investor 
and the target country. Table 4 reports estimation results using this interaction term, by splitting target countries into two groups (African and non-African countries).

Column (1) shows that Inst.Quality distance is significant, and exerts a negative impact on the hectares of land acquired in countries with higher quality of institution (-1.373). By contrast, when acquisitions occur in the lowest institutional quality (target) countries, the governance distance increases the amount of the hectares acquired $(-1.373+1.497=+0.123)$. Regression 3 and 5 highlight that this effect is driven by African target countries, confirming findings of the previous section. Indeed, in African countries when the target country has a low institutional quality, the effect of distance is positive and significant, while this is not the case elsewhere.

Thus, the main message from all this is that when the target country is weak in terms of institutions, largescale North-South FLA are particularly favoured, ${ }^{\text {xxvi }}$ while South-South FLA tend to be favoured - both in terms of number of contracts and the size of the investments - in target countries with relatively strong institutions.

\subsection{Robustness check: does data source and quality matter?}

As described in section 4.1, the quality of the Land Matrix data is the key issue for empirical analyses. Thus, as a robustness check, we run all previous regressions using data coming from more reliable sources only, i.e. governments and firms. Table A4 and A5 in Appendix present the results of estimations, as in Table 2 and 3 , but by using the subsample of data coming from more reliable sources. Similarly, figure A2, which is analogous to figure 3, reports a synthesis of our estimations by using this restricted source of data only, for African and non-African target countries. Results reported in tables A4 and A5 confirm previous general findings, maintaining the same signs and the same significance level. In particular, institutional distances maintain a negative and significant effect on the hectares acquired, while regulatory system quality (RegQuality) is confirmed to exert a positive and significant effect. Moreover, institutional distance maintains, overall, a significant negative effect on the number of contracts for all variables, with coefficients that are generally larger (in absolute value) than those estimated using all the data, and are slightly lower only for democracy and Voice and Accountability distances. 
The robustness check is particularly relevant for African countries; indeed, as mentioned in section 4, the share of unofficial (and less reliable) data is high for this continent, especially in terms of hectares acquired. Interestingly, the estimates obtained reinforce our previous findings. Indeed, as shown in figure A2, when the dependent variable is land, the distance in the level of democratization maintains a negative and significant impact; further, distance in corruption (both CPI and Corruption), regulatory quality (RegQuality), and stability of government (Stability) still show a positive impact on the hectares acquired. At the same time, the sign of coefficients remain negative when using the number of contracts as dependent variable. Hence, our major findings appear robust to the use of more reliable data for Africa as well.

\section{Conclusions}

The aim of this paper is to provide further cross-country evidence on the impact of institutional quality on foreign investments in land. Our approach differs in some respects from previous studies. Instead of checking whether and how the quality of institutions in target countries affects FLA, we investigate the role exerted by the distance in institutions between the target and the investor countries. Moreover, we use different measures of FLA (number of contracts and hectares acquired) which proxy, by and large, the impact of distance on the number of firms (extensive margin) and the size of investments of FLA and check whether the responsiveness of FLA in African countries and in countries with weak institutions is different from elsewhere. Finally, we check the robustness of our results with regard to the reliability of the data sources.

The results seem to confirm our expectations. We find quite robust evidence for the hypothesis that the distance in the quality of institutions exerts a negative effect on bilateral FLA, measured either by the hectares acquired or by the number of contracts. The greater the gap in governance and democracy between the investor and the target countries, the lower the amount of FLA. Thus, FLA seem to follow the same pattern found in the literature for general FDI (Bénassy-Quéré et al, 2007; Demir, Hu, 2016; Cezar, Escobar, 2015; Aleksynska, Havrylchyk, 2013), and confirm the hypothesis that firms from countries with stronger institutions face higher costs when investing in those with weak institutions. This sheds new light on the recent growth of South-South FLA. Indeed, besides the key factors based on the lack (abundance) of land and water in the investing (target) countries already underlined in the literature, we also find that similarity in 
the political regime and governance may drive countries from the South to invest in that part of the South which is rich in natural resources.

The hypothesis that Africa follows a clearly different pattern from other regions is confirmed by the results. Indeed, while political distance negatively affects FLA, the gap in governance fosters the amount of hectares acquired in Africa, though not the number of contracts. These results suggest that the weaker the level of governance in African target countries, the more investors prefer large-scale contracts. Finally, this evidence also confirms that the dependent variable used in empirical analysis matters, as it provides different information about FLA, and could partly help to explain the ambiguous findings in the literature. Moreover, by using the most reliable data sources only, the main conclusion of our results are confirmed.

These findings may have some interesting implications, as they show that reducing corruption and improving overall governance in the target country may significantly influence the number of investors and the amount of hectares acquired, but that the direction of these effects depends upon the geographical region and the institutional quality of the target country. Further, our results also show that an improvement in overall governance and pluralism in countries with the weakest institutions may change the pattern of FLA, in terms of origin of investing firms (South versus North). Whether these effects would be positive or negative from the point of view of the target country is a highly relevant question but outside the scope of this paper.

On the whole, our results provide some insight into the impact of institutional quality on the pattern FDI in a (natural resources) sector where the public sector plays a key role. Empirical cross-country evidence for FLA is rather scant, although its role in the overall pattern of South-South FDI is increasingly important and highly sensitive politically. This paper aims to help fill a gap in current knowledge on this issue. We are aware, however, of the need to improve and widen the empirical analysis in different directions. Although our main findings do not seem to be seriously affected by the use of unofficial sources, improvements in the quality and availability of data are essential for a full understanding of the potential determinants and effects of FLA. This would allow to explore a number of issues related to the institutional drivers of FLA, such as whether the responsiveness of FLA to institutional quality differs according to the public or private nature of the investor, to the final use of the land acquired (biofuels, food or others) or to the ownership of land and business model prevailing in the target country. 


\section{REFERENCES}

Aizenman, J., Spiegel Mark M. (2006) Institutional Efficiency, Monitoring Costs, and the Investment Share of FDI.

Review of International Economics, 14(4), 683-697

Aleksynska, M., Havrylchyk O. (2013). FDI from the south: The role of institutional distance and natural resources. European Journal of Political Economy, 29 , 38-53

Anderson, J. and E. van Wincoop. 2003. Gravity with Gravitas: A Solution to the Border Puzzle. American Economic Review 93(1): 170-192.

Anseeuw, W., Boche, M., Breu, T., Giger, M., Lay, J., Messerli, P., Nolte, K., (2012). Transnational Land Deals for Agriculture in the Global South: Analytical Report based on the Land Matrix Database. International Land Coalition, Rome, Italy.

Arezki, R., K. Deininger, \& H. Selod. (2015). What Drives the Global "Land Rush"? The World Bank Economic Review. 29 (2), 207-233.

Asiedu, E. (2002). On the Determinants of Foreign Direct Investment to Developing Countries: Is Africa Different? World Development, 30, 107-119.

Asiedu, E. (2006). Foreign Direct Investment in Africa: The Role of Natural Resources, Market Size, Government Policy, Institutions and Political Instability. The World Economy, 29, 63-77.

Asiedu, E., Lien, D. (2011). Democracy, foreign direct investment and natural resources. Journal of International Economics, 84, 99-111.

Baier, S. L. and J. H. Bergstrand. 2007. Do free trade agreements actually increase members' international trade? Journal of International Economics 71(1) :72-95.

Baldwin, R. and D. Taglioni. 2006. Gravity for dummies and dummies for gravity equations. NBER Working Paper 12156. Cambridge, MA: National Bureau of Economic Research.

Bénassy-Quéré, A., Coupet, M., \& Mayer, T. (2007). Institutional Determinants of Foreign Direct Investment. The World Economy, 30, 764-782.

Bergstrand, J.H., Egger, P. (2007). A knowledge-and-physical-capital model of international trade flows. Foreign direct investment and multinational enterprises. Journal of International Economics, 73: 278-308.

Bergstrand, J.H., Egger, P. (2010) “A General Equilibrium Theory for Estimating Gravity Equations of Bilateral FDI, Final Goods Trade, and Intermediate Trade Flows”, in P. A. G. van Bergeijk and S. Brakman (eds.), The Gravity Model in International Trade (Cambridge: Cambridge University Press): 29-70.

Bergstrand, J. H. P. Egger (2013a), 'Shouldn’t Physical Capital also Matter for Multinational Enterprise Activity?', Review of International Economics, 21 (5): 945-65.

Bergstrand, J. H. , P. Egger (2013b), 'What Determines BITs?', Journal of International Economics, 90 (1): $107-22$. Bujko, M., Fischer, C., Krieger, T., Meierrieks, D. (2016) How Institutions Shape Land Deals: The Role of Corruption, Homo Oeconomicus: Journal of Behavioral and Institutional Economics, Springer, 33(3): 205-217;

Cezar, R. Escobar, O.R (2015) Institutional distance and foreign direct investment, Review of World Economics $151: 713-733$.

Cotula, L. 2011. Land deals in Africa: What is in the contracts? London: IIED. 
Cotula, L., Vermeulen, S., Leonard, R., \& Keeley, J. 2009. Land grab or development opportunity? Agricultural investment and international land deals in Africa. London: IIED.

Daude, C., Stein, E. 2007. The quality of institutions and foreign direct investment. Economics and Politics. 19(3): 317344.

De Maria, M. (2015) Trading the Untradeable: a Gravity Model for Large Scale Acquisitions, 2015 World Bank Conference on Land and Poverty, The World Bank. Washington DC March 23-27, 2015;

Demir, F., Hu, C., (2016) Institutional Differences and the Direction of Bilateral Foreign Direct Investment Flows: Are South-South Flows any Different than the Rest? The World Economy 39: 2000-2024.

FAO (2013), Trends and impact of foreign investment in developing country agriculture. Evidence from case studies. Rome.

Globerman, S., Shapiro D. (2002) Global Foreign Direct Investment Flows: The Role of Governance Infrastructure. World Development 30(11):1899-919.

Lay, J., Nolte, K. (2014) Land grabs or simply investments? Determinants of foreign large scale land acquisitions in developing countries, GIGA;

Li, Q., Resnick, A. (2003) Reversal of Fortunes: Democratic Institutions and Foreign Direct Investment Inflows to Developing Countries. International Organization 57 (1), 175-211.

Heckman, J., (1979) Sample Selection Bias as a Specification Error. Econometrica 47(1), 153-161.

Helpman E, Melitz M, Rubinstein Y. (2008). Estimating trade flows: Trading Partners and Trading Volumes. Quartely Journal of Economics, 123(2), pp. 441-487.

Kleemann, L., Thiele, R., (2015) Rural welfare implications of large scale land acquisitions in Africa: A theoretical framework. Economic Modelling. 51:269-279.

Kleinert , J. Toubal , F. (2010) Gravity for FDI, Review of International Economics, 18(1):1-13;

Lay, J., Nolte, K., (2014) Land grabs or simply investments? Determinants of foreign large scale land acquisitions in developing countries, German Institute of Global and Area Studies, Hamburg, Germany;

Li, Q. ,A. Resnick (2003). Reversal of Fortunes: Democratic Institutions and Foreign Direct Investment Inflows to Developing Countries, International Organization, 57, 1, 175-211.

Magee C. (2008) New measures of trade creation and trade diversion. Journal of International Economics 75, 349-362.

Markusen, J. R. (2002), Multinational Firms and the Theory of International Trade (Cambridge, MA: MIT Press).

Markusen, J. R., K. E. Maskus (2002), Discriminating Among Alternative Theories of the Multinational Enterprise, Review of International Economics, 10 (4): 694-707

Messerli P., Giger M., Dwyer M.B., Breu T., Eckert S. (2014). The geography of large-scale land acquisitions: Analysing socio-ecological patterns of target contexts in the global South. Applied Geography 53:449-459

Nolte, K. Voget-Kleschin, L. (2014). Consultation in Large-Scale Land Acquisitions:An Evaluation of Three Cases in Mali”. World Development, 64: 654-668.

Oya, C. (2013). Methodological reflections on "land grab" databases and the "land grab" literature "rush". Journal of Peasant Studies, 40: 503-520

Santos Silva, J.M.C. Tenreyro, S. (2006). The log of gravity. The Review of Economics and Statistics 88(4): 641-658. Santos Silva, J.M.C., Tenreyro, S. (2011). Further simulation evidence on the performance of the Poisson pseudo- 
maximum likelihood estimator, Economics Letters, 112(2), 220-222.

Schoneveld, G.C. (2014). The geographic and sectoral patterns of large-scale farmland investments in sub-Saharan Africa. Food Policy 48: 34-50

Stein, E., Daude C. (2001). Institutions, Integration and the Location of Foreign Direct Investment, in New Horizons of Foreign Direct Investment, OECD Global Forum on International Investment (Paris).

Treisman, D. (2007). What have we learned about the causes of corruption from ten years of crossnational empirical research?. Annual Review of Political Science 10: 211-244

UNCTAD (2009) World Investment Report 2009: Transnational corporations, agricultural production, and development. New York and Geneva: United Nations.

Venables, A. J., Ruta, M. (2012) International Trade in Natural Resources: Practice and policy. Annual Review of Resource Economics, 4(1): 331-352.

Von Braun, J., Meinzen-Dick, R. (2009). Land Grabbing” by foreign investors in developing countries: Risks and opportunities. IFPRI Policy Brief 13.

Wei, S. J. (2000). How Taxing is Corruption on Internal Investors? Review of Economics and Statistics. 82(1): 1-11.

Wolford, W., Borras Jr. S.M., Hall, R., White, B. (2013) Governing Global Land Deals: the Role of State in the Rush for Land, Development and Change, 44(2):189-210.

World Bank, (2011) Rising Global Interest in Farmland: Can it Yield Sustainable and Equitable Benefits? World Bank, Washington, D.C., USA. 
Table 1. Foreign Land Acquisitions by investor and target region (2015)

\begin{tabular}{|c|c|c|c|c|c|c|c|c|c|c|}
\hline \multirow[t]{2}{*}{ Hectares of land } & \multicolumn{9}{|c|}{ Target Region } & \multirow[b]{2}{*}{$\%$} \\
\hline & Americas & East Europe & East Asia & $\begin{array}{c}\text { East and } \\
\text { Southern } \\
\text { Africa }\end{array}$ & $\begin{array}{l}\text { North } \\
\text { Africa }\end{array}$ & $\begin{array}{l}\text { Rest of } \\
\text { Europe }\end{array}$ & South Asia & West Africa & Total & \\
\hline \multicolumn{11}{|l|}{ Investor Region } \\
\hline Americas & $1,474,162$ & $1,590,332$ & $2,394,501$ & $2,163,210$ & 0 & 0 & 84,833 & $3,680,446$ & $11,387,484$ & $28.5 \%$ \\
\hline East Europe & 0 & 330,000 & 0 & 301,700 & 0 & 0 & 0 & 130,000 & 761,700 & $1.9 \%$ \\
\hline East Asia & 782,455 & 205,667 & $6,550,658$ & $1,061,624$ & 2,732 & 0 & 20,420 & $1,218,822$ & $9,842,378$ & $24.6 \%$ \\
\hline \multicolumn{11}{|l|}{ East and Southern } \\
\hline Africa & 4,351 & 750 & 0 & 740,525 & 0 & 0 & 0 & 182,425 & 928,051 & $2.3 \%$ \\
\hline Middle East & 380,173 & 34,000 & 2,696 & $2,555,933$ & 794,820 & 20,000 & 30,651 & 72,979 & $3,891,252$ & $9.7 \%$ \\
\hline North Africa & 0 & 0 & 0 & 305,785 & 0 & 0 & 0 & 330,150 & 635,935 & $1.6 \%$ \\
\hline Rest of Europe & 951,211 & $1,320,276$ & 376,580 & $2,718,781$ & 40,054 & 0 & 76,131 & $5,076,154$ & $10,559,187$ & $26.4 \%$ \\
\hline South Asia & 423,961 & 0 & 534,830 & 409,035 & 0 & 0 & 641 & 511,108 & $1,879,575$ & $4.7 \%$ \\
\hline West Africa & 0 & 0 & 0 & 7,500 & 0 & 0 & 0 & 69,550 & 77,050 & $0.2 \%$ \\
\hline Total & $4,016,313$ & $3,481,025$ & $9,859,265$ & $10,264,093$ & 837,606 & 20,000 & 212,675 & $11,271,634$ & $39,962,612$ & $100.0 \%$ \\
\hline \multirow[t]{2}{*}{ Number of contracts } & \multicolumn{9}{|c|}{ Target Region } & \\
\hline & Americas & East Europe & East Asia & $\begin{array}{c}\text { East and } \\
\text { Southern } \\
\text { Africa }\end{array}$ & $\begin{array}{l}\text { North } \\
\text { Africa }\end{array}$ & $\begin{array}{l}\text { Rest of } \\
\text { Europe }\end{array}$ & South Asia & West Africa & Total & $\%$ \\
\hline \multicolumn{11}{|l|}{ Investor Region } \\
\hline Americas & 103 & 8 & 17 & 28 & 0 & 0 & 3 & 26 & 185 & $15.8 \%$ \\
\hline East Europe & 0 & 3 & 0 & 4 & 0 & 0 & 0 & 2 & 9 & $0.8 \%$ \\
\hline East Asia & 44 & 5 & 307 & 31 & 1 & 0 & 3 & 26 & 417 & $35.7 \%$ \\
\hline \multicolumn{11}{|l|}{ East and Southern } \\
\hline Africa & 1 & 1 & 0 & 37 & 0 & 0 & 0 & 8 & 47 & $4.0 \%$ \\
\hline Middle East & 15 & 1 & 2 & 39 & 5 & 1 & 5 & 9 & 77 & $6.6 \%$ \\
\hline North Africa & 0 & 0 & 0 & 8 & 0 & 0 & 0 & 4 & 12 & $1.0 \%$ \\
\hline Rest of Europe & 73 & 45 & 39 & 106 & 4 & 0 & 3 & 83 & 353 & $30.2 \%$ \\
\hline South Asia & 2 & 0 & 17 & 36 & 0 & 0 & 2 & 5 & 62 & $5.3 \%$ \\
\hline West Africa & 0 & 0 & 0 & 1 & 0 & 0 & 0 & 5 & 6 & $0.5 \%$ \\
\hline Total & 238 & 63 & 382 & 290 & 10 & 1 & 16 & 168 & 1168 & $100.0 \%$ \\
\hline
\end{tabular}

Notes: the number of hectares acquired (contracts) have been aggregated, first at the country level and then at the target/ investor region level, and cumulated during the analysed period. Source: Authors' analysis based on Land Matrix dataset, 2000-2015 
Table 2 - Impact of institutional distance on FLAs: effects on the hectares acquired

\begin{tabular}{|c|c|c|c|c|c|c|c|c|c|c|c|}
\hline \multirow[b]{2}{*}{$\begin{array}{l}\text { Dependent variable: } \\
\text { Hectares of Land }\end{array}$} & \multirow[b]{2}{*}{ (1) } & \multicolumn{10}{|c|}{ Institutional / political variable distance } \\
\hline & & $\begin{array}{l}\text { Polity } \\
\text { (2) }\end{array}$ & $\begin{array}{l}\text { PolRights } \\
\text { (3) }\end{array}$ & $\begin{array}{l}\text { CPI } \\
\text { (4) }\end{array}$ & $\begin{array}{l}\text { Corr. } \\
(5)\end{array}$ & $\begin{array}{l}\text { Accoun. } \\
\text { (6) }\end{array}$ & $\begin{array}{l}\text { RoL } \\
\text { (7) }\end{array}$ & $\begin{array}{l}\text { Stability } \\
\text { (8) }\end{array}$ & $\begin{array}{l}\text { RegQuality } \\
\text { (9) }\end{array}$ & $\begin{array}{l}\text { Effectiveness } \\
(10)\end{array}$ & $\begin{array}{l}\text { Inst.Quality } \\
\text { (11) }\end{array}$ \\
\hline Log Distance & $\begin{array}{c}-1.2470 * * * \\
(0.0701)\end{array}$ & $\begin{array}{c}-1.1580^{* * *} \\
(0.0706)\end{array}$ & $\begin{array}{c}-1.1234^{* * *} \\
(0.0705)\end{array}$ & $\begin{array}{c}-1.2619^{* * *} \\
(0.0702)\end{array}$ & $\begin{array}{c}-1.2482^{* * *} \\
(0.0695)\end{array}$ & $\begin{array}{c}-1.2371^{* * *} \\
(0.0717)\end{array}$ & $\begin{array}{c}-1.2576^{* * *} \\
(0.0696)\end{array}$ & $\begin{array}{c}-1.2451^{* * *} \\
(0.0695)\end{array}$ & $\begin{array}{c}-1.2486 * * * \\
(0.0702)\end{array}$ & $\begin{array}{c}-1.2472^{* * *} \\
(0.0700)\end{array}$ & $\begin{array}{c}-1.2485^{* * *} \\
(0.0697)\end{array}$ \\
\hline Common Language & $\begin{array}{c}0.5972^{* * *} \\
(0.1379)\end{array}$ & $\begin{array}{c}0.4417^{* * *} \\
(0.1305)\end{array}$ & $\begin{array}{c}0.5849 * * * \\
(0.1425)\end{array}$ & $\begin{array}{c}0.6141^{* * *} \\
(0.1402)\end{array}$ & $\begin{array}{c}0.6000^{* * *} \\
(0.1397)\end{array}$ & $\begin{array}{c}0.5082^{* * *} \\
(0.1402)\end{array}$ & $\begin{array}{c}0.6090^{* * *} \\
(0.1396)\end{array}$ & $\begin{array}{c}0.5934^{* * *} \\
(0.1373)\end{array}$ & $\begin{array}{c}0.5852^{* * *} \\
(0.1379)\end{array}$ & $\begin{array}{c}0.5970^{* * *} \\
(0.1386)\end{array}$ & $\begin{array}{c}0.6006^{* * *} \\
(0.1393)\end{array}$ \\
\hline Colonial relation & $\begin{array}{c}0.2651 \\
(0.2358)\end{array}$ & $\begin{array}{c}0.3263 \\
(0.2270)\end{array}$ & $\begin{array}{c}0.2322 \\
(0.2417)\end{array}$ & $\begin{array}{c}0.2544 \\
(0.2348)\end{array}$ & $\begin{array}{c}0.2623 \\
(0.2365)\end{array}$ & $\begin{array}{c}0.3107 \\
(0.2378)\end{array}$ & $\begin{array}{c}0.2509 \\
(0.2352)\end{array}$ & $\begin{array}{c}0.2715 \\
(0.2363)\end{array}$ & $\begin{array}{c}0.2843 \\
(0.2379)\end{array}$ & $\begin{array}{c}0.2658 \\
(0.2373)\end{array}$ & $\begin{array}{c}0.2609 \\
(0.2363)\end{array}$ \\
\hline RFE & $\begin{array}{c}-0.7765 * * * \\
(0.1722)\end{array}$ & $\begin{array}{c}-1.1156 * * * \\
(0.1822)\end{array}$ & $\begin{array}{c}-1.0533 * * * \\
(0.1845)\end{array}$ & $\begin{array}{c}-0.7760 * * * \\
(0.1733)\end{array}$ & $\begin{array}{c}-0.7751 * * * \\
(0.1729)\end{array}$ & $\begin{array}{c}-0.7859 * * * \\
(0.1716)\end{array}$ & $\begin{array}{c}-0.7706^{* * *} \\
(0.1729)\end{array}$ & $\begin{array}{c}-0.7839 * * * \\
(0.1714)\end{array}$ & $\begin{array}{c}-0.7902^{* * *} \\
(0.1715)\end{array}$ & $\begin{array}{c}-0.7768 * * * \\
(0.1724)\end{array}$ & $\begin{array}{c}-0.7738 * * * \\
(0.1730)\end{array}$ \\
\hline GDPSum & $\begin{array}{l}0.2337 * * \\
(0.0926)\end{array}$ & $\begin{array}{l}0.2187^{* *} \\
(0.0965)\end{array}$ & $\begin{array}{c}0.0833 \\
(0.0948)\end{array}$ & $\begin{array}{l}0.2217^{* *} \\
(0.0948)\end{array}$ & $\begin{array}{l}0.2327 * * \\
(0.0926)\end{array}$ & $\begin{array}{l}0.2337^{* *} \\
(0.0926)\end{array}$ & $\begin{array}{l}0.2335^{* *} \\
(0.0933)\end{array}$ & $\begin{array}{l}0.2296 * * \\
(0.0927)\end{array}$ & $\begin{array}{l}0.2094^{* *} \\
(0.0915)\end{array}$ & $\begin{array}{l}0.2321^{* *} \\
(0.0926)\end{array}$ & $\begin{array}{l}0.2328 * * \\
(0.0927)\end{array}$ \\
\hline $\begin{array}{l}\text { Institutional / political } \\
\text { distance }\end{array}$ & & $\begin{array}{c}-1.2479 * * * \\
(0.1933) \\
\end{array}$ & $\begin{array}{c}-0.5240 * * * \\
(0.1647) \\
\end{array}$ & $\begin{array}{c}-1.7372 * * \\
(0.7761) \\
\end{array}$ & $\begin{array}{l}-0.1576 \\
(0.4853) \\
\end{array}$ & $\begin{array}{c}-0.7819 * * * \\
(0.2774) \\
\end{array}$ & $\begin{array}{c}-1.0170^{* *} \\
(0.4514) \\
\end{array}$ & $\begin{array}{r}0.5701 \\
(0.4217) \\
\end{array}$ & $\begin{array}{l}1.1616^{* *} \\
(0.5158) \\
\end{array}$ & $\begin{array}{r}0.0377 \\
(0.6996) \\
\end{array}$ & $\begin{array}{l}-0.3274 \\
(0.5523) \\
\end{array}$ \\
\hline No. of obs. & 36420 & 34116 & 31414 & 34881 & 36420 & 36420 & 36420 & 36420 & 36420 & 36420 & 36420 \\
\hline $\mathrm{R}-\mathrm{Sq}$ & 0.45 & 0.46 & 0.44 & 0.45 & 0.45 & 0.45 & 0.45 & 0.46 & 0.45 & 0.45 & 0.45 \\
\hline
\end{tabular}

Notes: 'Institutional / political distance' refers to the absolute difference of the variable reported on the top of the column. Robust standard errors in parenthesis. All regressions use the PPML estimator and include Investor-year, Target-year and year fixed effects not reported. $* * *, * * *$ indicate significance at 1,5 and 10 percent level, respectively.

Table 3- Impact of institutional distance on FLAs: effects on the number of contracts

\begin{tabular}{|c|c|c|c|c|c|c|c|c|c|c|c|}
\hline \multirow[b]{2}{*}{$\begin{array}{l}\text { Dependent variable: } \\
\text { Number of contracts }\end{array}$} & \multirow[b]{2}{*}{ (1) } & \multicolumn{10}{|c|}{ Institutional / political variable distance } \\
\hline & & $\begin{array}{l}\text { Polity } \\
\text { (2) }\end{array}$ & $\begin{array}{l}\text { PolRights } \\
\text { (3) }\end{array}$ & $\begin{array}{l}\text { CPI } \\
(4)\end{array}$ & $\begin{array}{l}\text { Corr. } \\
\text { (5) }\end{array}$ & $\begin{array}{c}\text { Accoun. } \\
(6)\end{array}$ & $\begin{array}{l}\text { RoL } \\
(7)\end{array}$ & $\begin{array}{l}\text { Stability } \\
\text { (8) }\end{array}$ & $\begin{array}{l}\text { RegQuality } \\
\text { (9) }\end{array}$ & $\begin{array}{l}\text { Effectiveness } \\
\text { (10) }\end{array}$ & $\begin{array}{l}\text { Inst.Quality } \\
\text { (11) }\end{array}$ \\
\hline Log Distance & $\begin{array}{c}-1.3673^{* * *} \\
(0.0388)\end{array}$ & $\begin{array}{c}-1.3288^{* * *} \\
(0.0392)\end{array}$ & $\begin{array}{c}-1.2706^{* * *} \\
(0.0402)\end{array}$ & $\begin{array}{c}-1.4054^{* * *} \\
(0.0376)\end{array}$ & $\begin{array}{c}-1.3711^{* * *} \\
(0.0369)\end{array}$ & $\begin{array}{c}-1.2980^{* * *} \\
(0.0388)\end{array}$ & $\begin{array}{c}-1.3934^{* * *} \\
(0.0371)\end{array}$ & $\begin{array}{c}-1.3757^{* * *} \\
(0.0384)\end{array}$ & $\begin{array}{c}-1.3633^{* * *} \\
(0.0368)\end{array}$ & $\begin{array}{c}-1.3831 * * * \\
(0.0370)\end{array}$ & $\begin{array}{c}-1.3646 * * * \\
(0.0367)\end{array}$ \\
\hline Common Language & $\begin{array}{c}0.5813^{* * *} \\
(0.0911)\end{array}$ & $\begin{array}{c}0.6375^{* * *} \\
(0.0867)\end{array}$ & $\begin{array}{c}0.5223^{* * *} \\
(0.0892)\end{array}$ & $\begin{array}{c}0.6645^{* * *} \\
(0.0824)\end{array}$ & $\begin{array}{c}0.6332 * * * \\
(0.0843)\end{array}$ & $\begin{array}{c}0.4853^{* * *} \\
(0.0875)\end{array}$ & $\begin{array}{c}0.6173^{* * *} \\
(0.0863)\end{array}$ & $\begin{array}{c}0.6040^{* * *} \\
(0.0890)\end{array}$ & $\begin{array}{c}0.6074^{* * *} \\
(0.0871)\end{array}$ & $\begin{array}{c}0.6060^{* * *} \\
(0.0847)\end{array}$ & $\begin{array}{c}0.6221^{* * *} \\
(0.0837)\end{array}$ \\
\hline Colonial relation & $\begin{array}{c}0.5884 * * * \\
(0.1118)\end{array}$ & $\begin{array}{l}0.5811^{* * *} \\
(0.1079)\end{array}$ & $\begin{array}{c}0.6856 * * * \\
(0.1096)\end{array}$ & $\begin{array}{c}0.6000^{* * *} \\
(0.1089)\end{array}$ & $\begin{array}{c}0.6159 * * * \\
(0.1086)\end{array}$ & $\begin{array}{c}0.7013^{* * *} \\
(0.1084)\end{array}$ & $\begin{array}{c}0.5791^{* * *} \\
(0.1106)\end{array}$ & $\begin{array}{c}0.5912^{* * *} \\
(0.1107)\end{array}$ & $\begin{array}{c}0.6000^{* * *} \\
(0.1099)\end{array}$ & $\begin{array}{c}0.5776 * * * \\
(0.1095)\end{array}$ & $\begin{array}{c}0.6076 * * * \\
(0.1091)\end{array}$ \\
\hline RFE & $\begin{array}{l}-0.0722 \\
(0.0774)\end{array}$ & $\begin{array}{c}0.0727 \\
(0.0779)\end{array}$ & $\begin{array}{c}0.1190 \\
(0.0772)\end{array}$ & $\begin{array}{l}-0.0309 \\
(0.0740)\end{array}$ & $\begin{array}{l}-0.0161 \\
(0.0735)\end{array}$ & $\begin{array}{c}0.0015 \\
(0.0696)\end{array}$ & $\begin{array}{l}-0.0158 \\
(0.0750)\end{array}$ & $\begin{array}{l}-0.0537 \\
(0.0810)\end{array}$ & $\begin{array}{l}-0.0182 \\
(0.0762)\end{array}$ & $\begin{array}{l}-0.0388 \\
(0.0762)\end{array}$ & $\begin{array}{c}0.0141 \\
(0.0737)\end{array}$ \\
\hline GDPSum & $\begin{array}{c}0.2682 * * * \\
(0.0638)\end{array}$ & $\begin{array}{c}0.1297 * * \\
(0.0651)\end{array}$ & $\begin{array}{c}0.1307 * * \\
(0.0649)\end{array}$ & $\begin{array}{c}0.2236^{* * *} \\
(0.0668)\end{array}$ & $\begin{array}{c}0.2080 * * * \\
(0.0647)\end{array}$ & $\begin{array}{c}0.2346 * * * \\
(0.0620)\end{array}$ & $\begin{array}{c}0.2325 * * * \\
(0.0652)\end{array}$ & $\begin{array}{c}0.2743^{* * *} \\
(0.0629)\end{array}$ & $\begin{array}{c}0.2120^{* * *} \\
(0.0643)\end{array}$ & $\begin{array}{c}0.2653^{* * *} \\
(0.0658)\end{array}$ & $\begin{array}{c}0.2158 * * * \\
(0.0644)\end{array}$ \\
\hline $\begin{array}{l}\text { Institutional / political } \\
\text { distance }\end{array}$ & & $\begin{array}{c}-1.0164^{* * *} \\
(0.1104) \\
\end{array}$ & $\begin{array}{c}-0.9121 * * * \\
(0.1099) \\
\end{array}$ & $\begin{array}{c}-4.8935^{* * *} \\
(0.5193) \\
\end{array}$ & $\begin{array}{c}-2.7352^{* * *} \\
(0.3008) \\
\end{array}$ & $\begin{array}{c}-1.5161^{* * *} \\
(0.1694)\end{array}$ & $\begin{array}{c}-3.4134^{* * *} \\
(0.3528) \\
\end{array}$ & $\begin{array}{c}-1.3010^{* * *} \\
(0.2476) \\
\end{array}$ & $\begin{array}{c}-2.9272 * * * \\
(0.3104) \\
\end{array}$ & $\begin{array}{c}-5.1262 * * * \\
(0.6396) \\
\end{array}$ & $\begin{array}{c}-3.9681^{* * *} \\
(0.4016) \\
\end{array}$ \\
\hline No. of obs. & 36420 & 34116 & 31414 & 34881 & 36420 & 36420 & 36420 & 36420 & 36420 & 36420 & 36420 \\
\hline $\mathrm{R}-\mathrm{Sq}$ & 0.51 & 0.56 & 0.57 & 0.54 & 0.53 & 0.56 & 0.53 & 0.50 & 0.53 & 0.53 & 0.54 \\
\hline
\end{tabular}

Notes: 'Institutional / political distance' refers to the absolute difference of the variable reported on the top of the column. Robust standard errors in parenthesis. All regressions use the PPML estimator and include Investor-year, Target-year and year fixed effects not reported. $* * *, * * *$ indicate significance at 1,5 and 10 percent level, respectively. 
Table 4 - Impact of institutional distance on FLAs by institutional quality in the target country

\begin{tabular}{|c|c|c|c|c|c|c|}
\hline & \multicolumn{6}{|c|}{ Dependent variables: } \\
\hline & Hectares & Contracts & Hectares & Contracts & Hectares & Contracts \\
\hline & \multicolumn{2}{|c|}{ All countries } & \multicolumn{2}{|c|}{ African countries } & \multicolumn{2}{|c|}{ Non African countries } \\
\hline & $(1)$ & (2) & (3) & (4) & (5) & (6) \\
\hline \multirow[t]{2}{*}{ Log Distance } & $-1.2675^{* * *}$ & $-1.3623 * * *$ & $-0.5910 * * *$ & $-1.2430 * * *$ & $-1.1066 * * *$ & $-1.2450 * * *$ \\
\hline & $(0.0676)$ & $(0.0381)$ & $(0.2264)$ & $(0.0709)$ & $(0.0618)$ & $(0.0458)$ \\
\hline \multirow[t]{2}{*}{ Common Language } & $0.5601 * * *$ & $0.6248 * * *$ & $1.1012 * * *$ & $1.0909 * * *$ & 0.2064 & 0.0328 \\
\hline & $(0.1393)$ & $(0.0840)$ & $(0.1713)$ & $(0.0739)$ & $(0.2410)$ & $(0.1510)$ \\
\hline \multirow[t]{2}{*}{ Colonial relation } & 0.2870 & $0.6126^{* * *}$ & -0.0778 & $0.6878 * * *$ & 0.0705 & $0.5717^{* * *}$ \\
\hline & $(0.2401)$ & $(0.1084)$ & $(0.3085)$ & $(0.1264)$ & $(0.3657)$ & $(0.1794)$ \\
\hline \multirow[t]{2}{*}{ RFE } & $-0.7785 * * *$ & 0.0118 & $-0.6925 * * *$ & 0.0401 & $-0.7810 * * *$ & 0.0110 \\
\hline & $(0.1778)$ & $(0.0736)$ & $(0.2367)$ & $(0.1044)$ & $(0.1748)$ & $(0.0921)$ \\
\hline \multirow[t]{2}{*}{ GDPSum } & $0.2086 * *$ & $0.1908 * * *$ & 0.0705 & $-0.4736 * * *$ & 0.1056 & $0.1747^{*}$ \\
\hline & $(0.0927)$ & $(0.0644)$ & $(0.2882)$ & $(0.1747)$ & $(0.1157)$ & (0.0899) \\
\hline \multirow[t]{2}{*}{ Inst.Quality } & $-1.3732 * *$ & $-3.8554 * * *$ & 0.2927 & $-1.2440 * * *$ & $-2.4800 * * *$ & $-4.5979 * * *$ \\
\hline & $(0.5733)$ & $(0.4351)$ & $(0.8072)$ & $(0.3880)$ & $(0.8931)$ & $(0.6353)$ \\
\hline \multirow[t]{2}{*}{ Inst.Quality x Dummy } & $1.4970 * * *$ & -0.1851 & $1.7208 * *$ & 0.3022 & $1.1532^{* * *}$ & $-0.6344 * *$ \\
\hline & $(0.3896)$ & $(0.2147)$ & $(0.8708)$ & $(0.2796)$ & $(0.4389)$ & $(0.2804)$ \\
\hline No. of obs. & 36420 & 36420 & 11896 & 11896 & 14677 & 14677 \\
\hline $\mathrm{R}-\mathrm{Sq}$ & 0.45 & 0.54 & 0.46 & 0.58 & 0.58 & 0.58 \\
\hline
\end{tabular}

Notes: 'Inst.Quality' refers to the absolute difference of the variable; Dummy=1 if Institutional quality of target country is below the median value (see text). Robust standard errors in parenthesis. All regressions use the PPML estimator and include Investor-year, Target-year and year fixed effects not reported. $*, * *, * *$ indicate significance at 1,5 and 10 percent level, respectively.

Figure 1 - Foreign Land Acquisitions by target region (000 hectares)

Figure 2 - Foreign Land Acquisitions and Institutional Quality Distance (2015)

Figure 3 - Impact of institutional distance on FLAs in African and non-African countries 


\section{Footnotes}

' In 2012 the Committee on World Food Security adopted the Voluntary Guidelines on the Responsible Governance of Tenure of Land, Fisheries and Forests in the context of National Food Security. One of the main issue concerns agricultural investments.

${ }^{\text {ii }}$ For a critical review of the available dataset and analyses see, among others, Oja (2013), Schoneveld (2014) and Arezki et al (2015).

iii Land Matrix includes FLA in the period 2000-2015.

iv As explained in the data section, we do not include in our specification economic similarity because of collinearity.

v Overall, in the panel used for our estimations $92 \%$ of our country-pair-year data is zero.

${ }^{v i}$ The Land Matrix Global Observatory is a database compiled by NGOs and research institutes coordinated by the International Land Coalition (Anseeuw et al., 2012). Data are verified by the partners, and include deals starting from 2000.

vii These include: research papers and policy reports by international, local organisations and NGOs; personal information contributed through the Global Observatory website; field-based research projects; official government records; company websites; media reports.

viii As we consider only concluded deals, for sake of simplicity, from now on we will refer to them as "contracts". Data have been downloaded from Land Matrix in October 2015. Land Matrix database is continuously updated and, hence, information downloaded from the database could change overtime.

${ }^{i x}$ One example is Cambodia, where the government provides information about FLA through an official document. (Municipality and Province Investment Information, Kratie Province" downloadable from the government website

http://www.cambodiainvestment.gov.kh.). In Indonesia as well, data are easily accessible, even though sourced from investing firms.

${ }^{x}$ When considering only these more reliable sources, African countries account for the $44 \%$ of the total land acquired.

${ }^{x i}$ It is worth noting that "Rest of Europe" in Table 1 includes all Western Europe and Turkey. Hence the largest part of FLA from this area comes from Western Europe.

xii In 115 (out of 1050) contracts there are two or more foreign investing firms. Land Matrix does not provide information about the relative weight of each investor in the contract., so we have assumed that each investor contributes equally to the contract.

Accordingly, the number of hectares has been allocated in equal parts to the investing countries and the final number of contracts in our dataset is 1,168.

${ }^{\text {xiii }}$ We have also included a measure of the GDP similarity, measured as $\log \left[\left(G D P_{i}\right) *\left(G D P_{t}\right) /\left(G D P_{i}+G D P_{t}\right)^{2}\right]$. Its impact on FLA is negative and significant. However, we can't include both GDP variables (bilateral economic dimension and economic similarity) because of collinearity problems. This is no change in all the estimated results when is used GDP sum rather than GDP similarity. ${ }^{x i v}$ Non-agricultural land is measured as the difference between a country's total area and agricultural land. Both data come from WDI database.

${ }^{\mathrm{xv}}$ To check robustness we have also considered different measures of factor endowment (e.g. gross fixed capital formation per hectares of agricultural land). The main results of our estimations -not reported for lack of space but available on request - do not change.

${ }^{x v i}$ The use of a panel framework forces us to exclude all those measures of institutional quality that are not available for every year. xvii In particular, we use the POLITY2 variable, a modified version of the POLITY variable in order to facilitate the use of the measure in time-series analyses.

xviii http://www.transparency.org/research/cpi/

${ }^{\mathrm{xix}}$ We here define as "weak" a country with an average Inst.Quality, measured during the analysed period, below the value of 0.5 ; "strong", otherwise.

${ }^{\mathrm{xx}}$ To measure this effect we used results of column (1) Table 2: (=exp(0.597) - 1)

${ }^{x \times i}$ One exception concerns the distance in Regulatory quality. For this variable a wider gap exerts a positive effect although only on the amount of the hectares acquired. As it will be noted below, this countertrend is probably the outcome (average effect) of countries following a different (opposite) pattern.

xxii We measure these effects by using results of Table 2 , and Table A3

xxiii We split the dataset, instead of interacting the institutional and political variables with a dummy variable for African countries, to allow the traditional gravity and control variables to exert a different role in the two groups. The results show that the effect of country distance and of relative factor endowment variable is generally lower for African countries than for 'all other' target countries, while the effect of common language is generally high and significant only for African countries. Those coefficients are not reported, but are available upon request.

${ }^{\text {xxiv }}$ Note that, with the exception of Regulation quality, these variables were not significant in the estimations using all target countries (see Table 2)

${ }^{x x v}$ The annual median value of Inst.Quality for the target countries range between 0.3 and 0.4 during the analyzed period. 
xxvi Indeed, as mentioned before, the group "North" includes a few developed countries (West Europe, North America, Australia and Japan) showing definitely higher institutional distances from the target countries, compared to all other investors from South. 
Figure 1 - Foreign Land Acquisitions by target region (000 hectares)

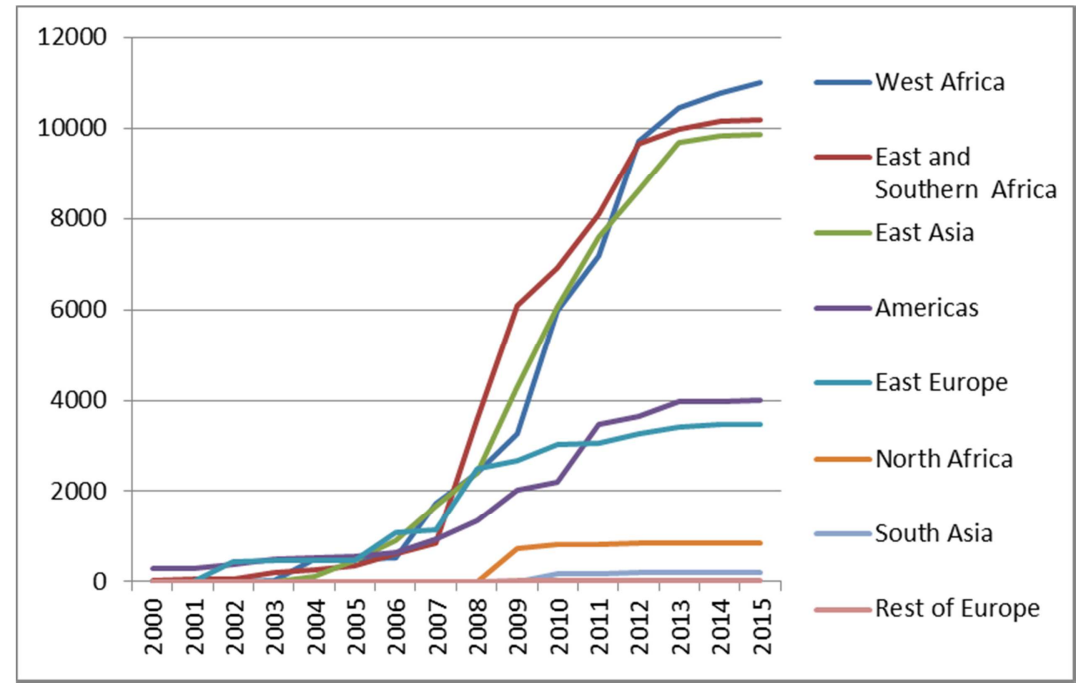

Source: Authors' analysis based on Land Matrix dataset, 2000-2015 
Figure 2 - Foreign Land Acquisitions and Institutional Quality Distance (2015)

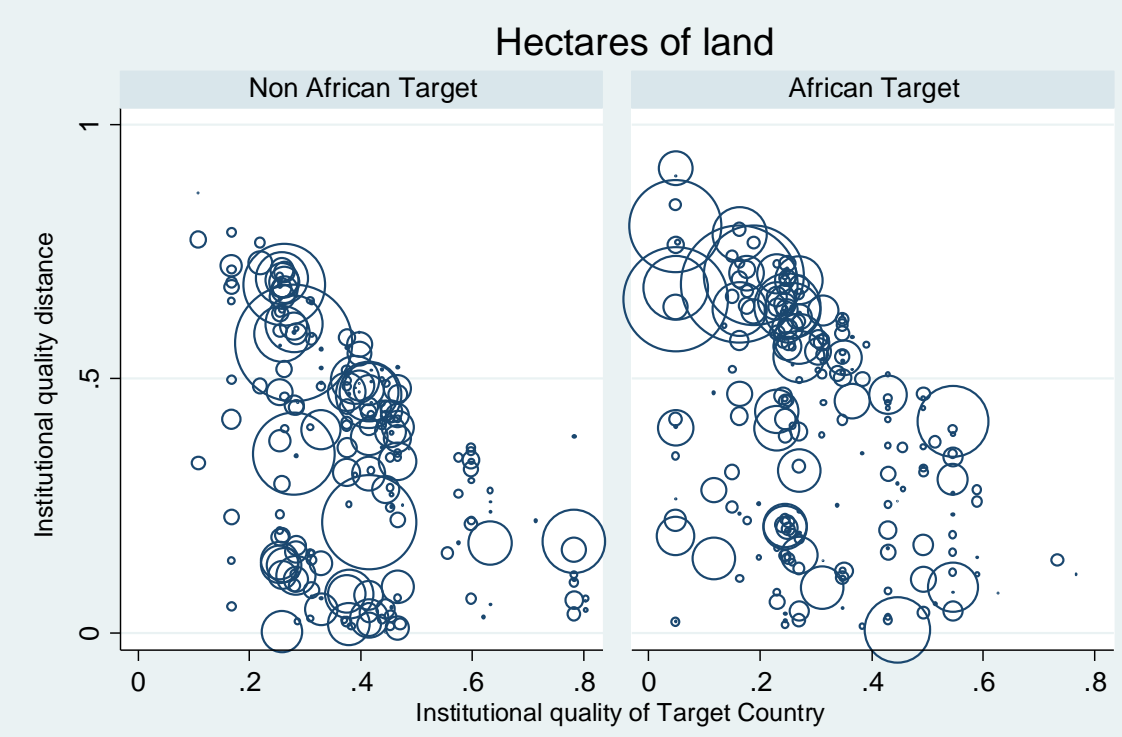

Number of contracts

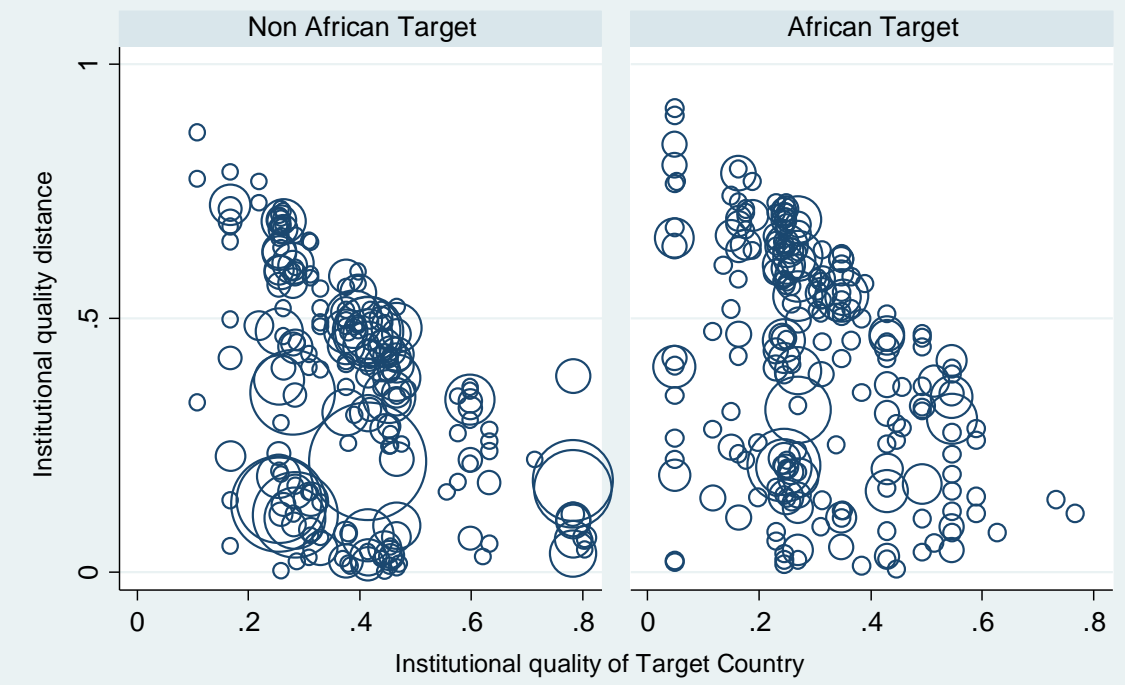

Source: Authors' analysis based on Land Matrix dataset Institutional Quality indicator from WGI (see text).

Note: Figure plots the total amount of hectares acquired (or the number of contracts) with respect of to the average index of institutional quality distance (Inst.Quality) and the average index of institutional quality of the target country. Institutional Quality distance is measured as the absolute difference in institutional quality variables between the origin and the destination country. The area of the circles is proportional to the amount of hectares of land acquired (of number of contracts) in the target country. 
Figure 3 - Impact of institutional distance on FLAs in African and non-African countries
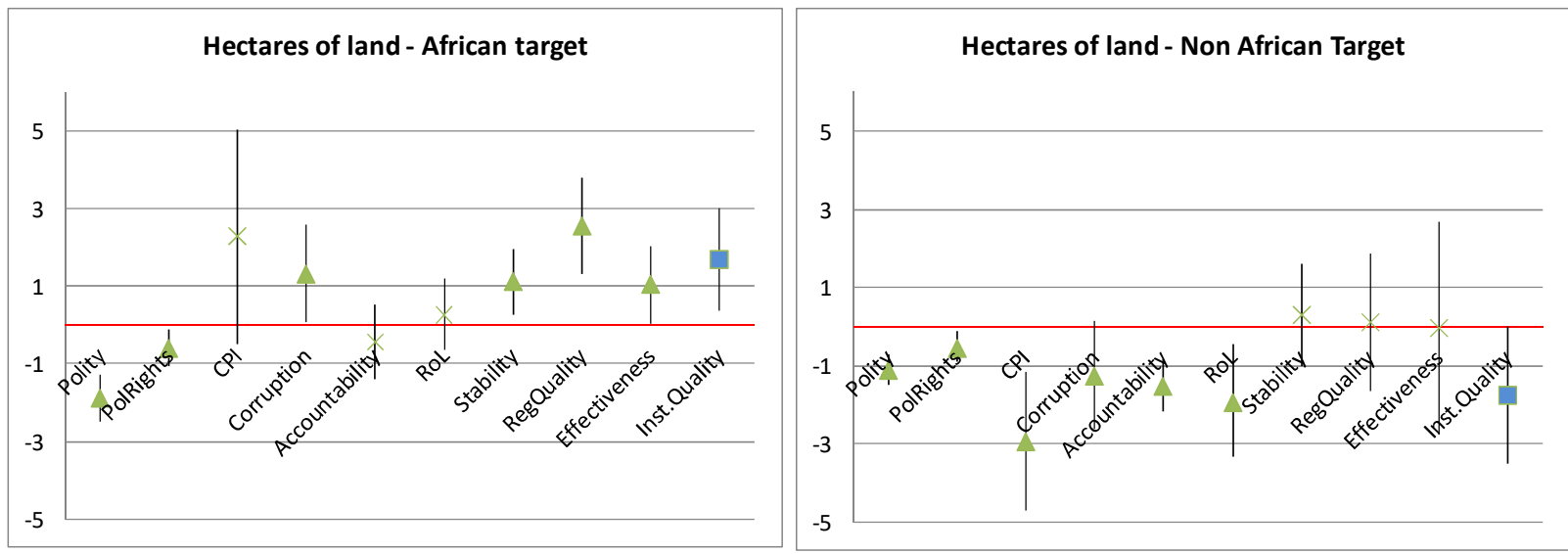

Number of contracts - African target

Number of contracts - Non African target
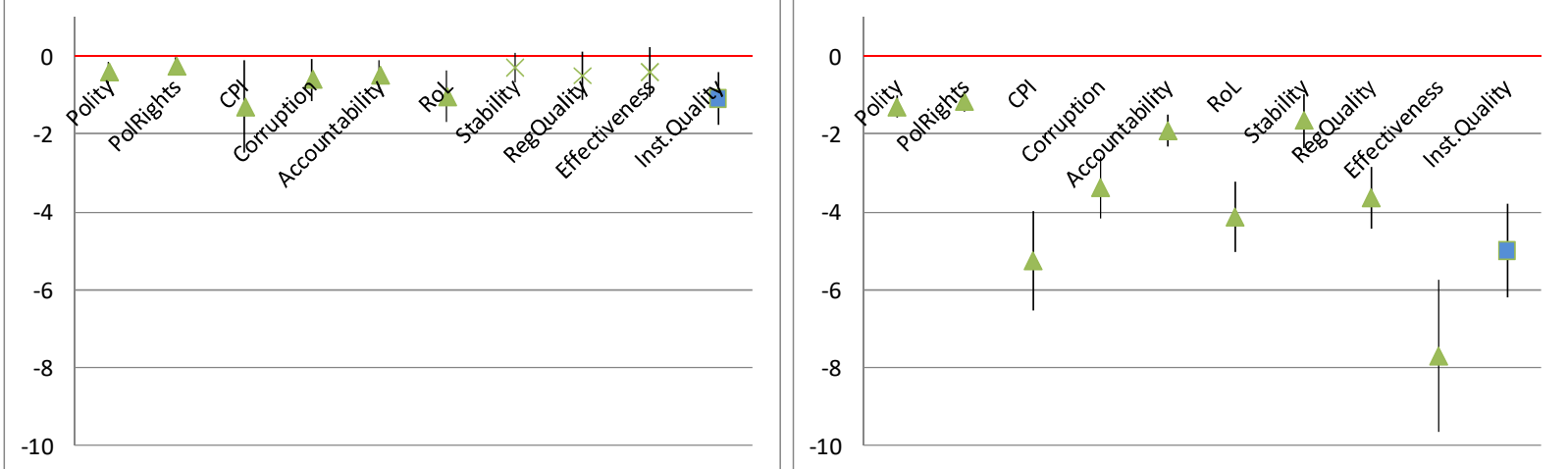

Note: The figure reports political and institutional distance effects on FLAs, estimated with equation (1), as in Tables 2 and 3, but distinguishing African and Non-African target countries. All regressions use the PPML estimator and include GDP sum, Relative factor endowment, distance, common language, common continent, colonial relationship, Investor-year, Target-year and year fixed effects not reported. All political and institutional covariates refer to the absolute difference of the variable between Investor and Target country. Figure reports all estimated coefficients, bar shows $95 \%$ confidence intervals. The X indicate significance below 5 percent level. 